\title{
ARTIKEL PENELITIAN PENDIDIKAN
}

Membangun Motivasi Belajar Siswa Sejarah di Tengah Pandemi Covid -19 dalam Pembelajaran Daring

Disusun untuk memenuhi tugas mata kuliah Metode Sejarah Dosen Pengampu:

Dr. Mohamad Zaenal Arifin Anis, M.Hum.

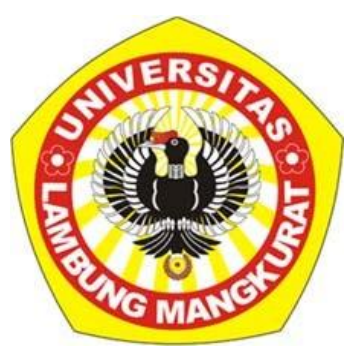

Disusun oleh:

Weni Amelia

1810111120006

PROGRAM STUDI PENDIDIKAN SEJARAH

FAKULTAS KEGURUAN DAN ILMU PENDIDIKAN

UNIVERSITAS LAMBUNG MANGKURAT

BANJARMASIN

2021 


\section{PENDAHULUAN}

Pendidikan adalah upaya yang dilakukan oleh individu secara sadar dan terencana untuk mewujudkan proses pembelajaran yang efektif dengan tujuan mendidik peserta didik dalam mengembangkan potensi dirinya. Namun, masih banyak sekali permasalahan-permasalahan di dalam dunia pendidikan yang dapat menghalangi terpenuhinya tujuan-tujuan yang diharapkan. Permasalahan di dalam pendidikan menjadikan prioritas utama yang harus dipecahkan, salah satunya menyangkut tentang masalah kualitas pendidikan. Kualitas pendidikan saat ini tengah mengalami tantangan sebagai dampak mewabahnya virus Covid-19. Covid-19 menjadi pandemik global yang penyebarannya begitu menghawatirkan. Akibatnya pemerintah harus bekerja sama untuk menekan laju penyebaran virus Covid-19 dengan mengeluarkan kebijakan agar seluruh warga masyarakat untuk melakukan social distancing atau menjaga jarak.2 Sehingga dengan adanya kebijakan tersebut seluruh aktivitas masyarakat yang dulu dilakukan di luar rumah dengan berkumpul dan berkelompok, kini harus diberhentikan sejenak dan diganti dengan beraktivitas di rumah masing-masing. Salah satu dampak social distancing juga terjadi pada sistem pembelajaran di sekolah. Berdasarkan Surat Edaran Nomor 4 Tahun 2020 tentang Pelaksanaan Kebijakan Pendidikan dalam masa darurat penyebaran virus, Mendikbud menghimbau agar semua lembaga pendidikan tidak melakukan proses belajar mengajar secara langsung atau tatap muka, melainkan harus dilakukan secara tidak langsung atau jarak jauh.3 Dengan adanya himbauan tersebut membuat semua lembaga pendidikan mengganti metode pembelajaran yang digunakan yaitu menjadi online atau dalam jaringan (daring) (Cahyani, Listiani, dan Larasati 2020).

Kendala pembelajaran secara daring memang dinilai masih banyak. Penyampaian materi tanpa tatap muka langsung dianggap masih kurang optimal dan siswa susah menyerap maksud dari pembelajaran yang disampaikan. Peralihan cara pembelajaran seperti ini, tentu tak mudah dilakukan. Kondisi darurat dan serba dadakan, tentunya membuat kaget 
semua pihak. Wabah corona telah menuntut kita belajar beradaptasi menjalankan proses pembelajaran dengan cara dan suasana yang benarbenar baru. Keadaan ini tentu saja memberikan dampak pada kualitas pembelajaran, siswa dan guru yang sebelumnya berinteraksi secara langsung dalam ruang kelas sekarang harus berinteraksi dalam ruang virtual yang terbatas. guru dituntut memberikan pengajaran yang baik, menciptakan suasana yang kondusif untuk belajar dan secara kreatif dan inovatif menggunakan media belajar yang menarik agar siswa dapat memahami materi pembelajaran dan tujuan pembelajaran dapat tercapai. Selain itu, motivasi belajar siswa juga berpengaruh dalam keberhasilan pembelajaran. Hal ini sesuai dengan yang diungkapkan oleh Emda bahwa proses pembelajaran akan mencapai keberhasilan apabila siswa memiliki motivasi belajar yang baik.4 Oleh karena itu motivasi belajar sangat penting untuk dimiliki oleh setiap siswa, baik motivasi intrinsik maupun ekstrinsik.

\section{PEMBAHASAN}

Motivasi belajar adalah kalimat yang terdiri dari dua kata yaitu motivasi dan belajar, yang keduanya memiliki arti tersendiri. Jika membahas mengenai motivasi, sering kali disandingkan dengan kata motif. Sesuai dengan penelusuran peneliti, motif dapat diartikan sebagai gerak atau sesuatu yang mendorong individu untuk bergerak.8 Sedangkan motivasi, menurut Mc Donald adalah suatu perubahan energi yang terjadi pada individu yang ditandai dengan timbulnya perasaan dan reaksi atau tindakan untuk mencapai tujuan tertentu.9 Sedangkan belajar menurut Slameto adalah suatu proses usaha untuk mendapatkan perubahan pada tingkah laku.10 Dengan demikian yang dimaksud dengan motivasi belajar adalah keseluruhan daya penggerak yang terletak di dalam diri peserta didik yang memunculkan niat. Tenaga pengajar dituntut memiliki kreatifitas dan sensitivitas untuk melihat hal berbeda di lingkungan sekitar untuk membuat rancangan penelitian sederhana. Keterlibatan siswa dalam penelitian, membuat dia menjadi bagian agen perubahan yang memahami lingkungan 
sekitarnya untuk bersikap kritis dan peduli kepada lingkungan sosial dan budayanya (Abbas: 2013).

Aspek-Aspek Motivasi Belajar Menurut Marilyn K. Gowing ada empat poin aspek-aspek motivasi belajar, adapun penjelasannya sebagai berikut:

a. Dorongan Mencapai Sesuatu Peserta didik merasa terdorong untuk berjuang demi mewujudkan keinginan dan harapan-harapannya.

b. Komitmen Komitmen adalah salah satu aspek yang cukup penting dalam proses belajar. Dengan memiliki komitmen yang tinggi, peserta didik memiliki kesadaran untuk belajar, mampu mengerjakan tugas dan mampu menyeimbangkan tugas.

c. Inisiatif Peserta didik dituntut untuk memunculkan inisiatif-inisiatif atau ide-ide baru yang akan menunjang keberhasilan dan kesuksesannya dalam menyelesaikan proses pendidikannya, karena ia telah mengerti dan bahkan memahami dirinya sendiri, sehingga ia dapat menuntun dirinya sendiri untuk melakukan hal-hal yang bermanfaat bagi dirinya dan juga orang di sekitarnya.

d. Optimis Sikap gigih, tidak menyerah dalam mengejar tujuan dan selalu percaya bahwa tantangan selalu ada, tetapi setiap dari kita memiliki potensi untuk berkembang dan bertumbuh lebih baik lagi.

Kemudian aspek-aspek motivasi belajar menurut Frandsen yaitu

a. Memiliki rasa ingin tahu yang besar terhadap hal baru. Oleh karena itu, selalu terdorong untuk belajar, demi mengejar cita-citanya. b. Kreatif, peserta didik terus berpikir dan menciptakan sesuatu yang baru, sehingga membuat dirinya berbeda dengan yang lainnya.

b. Adhetya Cahyani, Iin Diah Listiana, Sari Puteri Deta Larasati 128 | IQ (Ilmu Al-qur'an): Jurnal Pendidikan Islam | Volume 3 No. 012020

c. Menginginkan simpati dari orang tua, guru dan teman-temannya. Sebagai manusia biasa, kita menginginkan suatu pujian sebagai bentuk penghargaan terhadap apa yang telah kita lakukan maupun kita capai.

d. Memperbaiki kegagalan yang lalu dengan usaha yang baru. Tidak menutup kemungkinan, ketika kegagalan menghampiri kita, pasti terbesik rasa kecewa, tetapi bukan berarti membuat kita putus asa dan menyerah, melainkan harus terus berjuang demi menjemput kesuksesan kita. 
e. Merasa aman ketika telah menguasai materi pelajaran.

f. Memberlakukan ganjaran atau hukuman sebagai akhir dari belajar. Setiap dari kita pasti telah mengetahui dan percaya bahwa ketika melakukan hal yang baik, akan mendapatkan hasil yang baik pula, begitu pun sebaliknya. Dengan memiliki pemikiran seperti ini, akan memicu peserta didik untuk terus semangat dalam belajar.

Metode pembelajaran yang berbasis teknologi memiliki banyak penyebutan, seperti online, dalam jaringan (Daring) dan E-Learning. Kesemuanya memiliki makna yang sama, hanya saja konteks penempatan katanya yang sering di pertukar balikkan. E-Learning merupakan suatu sistem pembelajaran yang menggunakan media perangkat elektronik. ELearning adalah sebuah kegiatan pembelajaran melalui perangkat elektronik komputer yang tersambungkan ke internet, dimana peserta didik berupaya memperoleh bahan belajar yang sesuai dengan kebutuhannya.

Salah satu instruksi pemerintah tentang kegiatan yang dilakukan di rumah adalah kegiatan belajar. Belajar tidak boleh berhenti. Kegiatan belajar mengajar (KBM) dipindahkan di rumah, tetapi harus dikendalikan oleh guru atau dosen dan orang tua, dengan menggunakan pembelajaran jarak jauh. Pembelajaran Jarak Jauh ini dilakukan awalnya selama kurang lebih 14 hari, tetapi tidak menutup kemungkinan telah ditambahkan lagi karena melihat situasi dan kondisi perkembangan COVID-19 ini.

\section{PENUTUP}

\section{Kesimpulan}

Dalam mencari arti tentang difinisi sejarah pada masa kekinian ada begitu banyak yang dimunculkan oleh para sejarawan.(Abbas: 2013). Sebagai tenaga pendidik Guru harus menginformasikan kepada siswa sejarah itu sangan luas cakupannya, bisa dilihat dari sudut pandang yang berbeda-beda. Gagasan atau ide merupakan motor untuk memotivasi manusia dalam mencapai apa yang digagaskan, sesuai dengan jiwa zaman (Anis: 2013) Pembelajaran sejarah pada saat ini terus 
dikembangkan agar siswa dalam proses belajarnya tercapai dengan adanya berbagai metode untuk memotivasi pembelajaran siswa sejarah ditengah pandemic covid 19.

\section{DAFTAR PUSTAKA}

Abbas, E. W. (2013). Mewacanakan Pendidikan IPS. Mewacanakan Pendidikan IPS.

Anis, M. Z. A. (2013). ILMU SEJARAH SEBAGAI SUMBER PEMBELAJARAN IPS. Mewacanakan Pendidikan IPS, 149

Cahyani, A., Listiana, I. D., \& Larasati, S. P. D. (2020). Motivasi Belajar Siswa SMA pada Pembelajaran Daring di Masa Pandemi Covid19. IQ (Ilmu Al-qur'an): Jurnal Pendidikan Islam, 3(01), 123-140. 